International Research Journal of Management, IT \& Social Sciences
Available online at https://sloap.org/journals/index.php/irjmis/
Vol. 6 No. 6, November 2019, pages: 264 269
ISSN: 2395-7492
https://doi.org/10.21744/irjmis.v6n6.805

\title{
Market Reaction to the Rights Issue Announcement on the Indonesia Stock Exchange
}

Article history:

Received: 18 July 2019

Accepted: 30 September 2019

Published: 22 November 2019

\section{Keywords:}

abnormal return;

Indonesia stock exchange;

market efficiency;

market reaction;

rights issue;

\begin{abstract}
Rights issue or the issuance of pre-emptive rights are the rights granted by an issuer company made to its existing shareholders to buy new shares issued within a predetermined period of time. This study aims to empirically explain the differences in abnormal returns before and after the announcement of the rights issue and to determine the form of capital market efficiency in Indonesia. Data are collected from 27 listed companies in the Indonesia Stock Exchange (IDX) that conducted a rights issue in 2014-2018. The data analysis technique used is the Kolmogorov-Smirnov Normality Test and the Parametric Statistical Test with a paired sample t-test. Based on the results of hypothesis testing not found differences in abnormal returns both before and after the announcement date indicating the market does not react to the right issue event. The results of statistical tests show a downward trend of abnormal return which is proxied in the Cumulative Abnormal Return (CAR), implying a market tends to react negatively to the announcement of the rights issue. Rights issue information causes a new equilibrium price adjustment in the market, thus making the form of efficiency of the Indonesian capital market a semi-strong form.
\end{abstract}

2395-7492@ Copyright 2019. The Author. This is an open-access article under the CC BY-SA license (https://creativecommons.org/licenses/by-sa/4.0/) All rights reserved.

\section{Author correspondence:}

Ni Putu Linsia Dewi,

Faculty of Economic and Business, Udayana University, Denpasar, Indonesia.

Email address: linsiadewi1997@gmail.com

\section{Introduction}

There are three techniques for a company to increase equity that are: private placement, public offer, dan rights issue (Martino \& Busatto, 2018; Pratama \& Rahyuda, 2019). The rights issue is a more profitable choice for a company to gain additional equity compared to bank loans and the issuance of debt securities (Sihaloho \& Handayani, 2018; Putra \& Sedana, 2019). Balachandran et al., (2017), stated that a company spends more cost to do public placement rather than a rights issue. The rights issue is also a chance for an existing shareholder to increase their ownership of a company by purchasing new shares under the market price.

\footnotetext{
a Udayana University, Denpasar, Indonesia

${ }^{\mathrm{b}}$ Udayana University, Denpasar, Indonesia
} 
The investment decision made by the existing shareholders are based on the information contained in the announcement of the rights issue. An event study is a study to establish the information content of rights issues on market reaction that is shown on the stock price. The market reaction can be measured by returns as changes in stock prices or abnormal returns. Hartono (2017), defines abnormal return as a measurement tool to see the market reaction obtained from the difference between the actual return and expected returns. Positive abnormal returns reflect actual returns are greater than expected returns, which implies a positive market reaction. A positive market reaction will lead to an increase in sales of company shares and stock prices because investors make transactions around the announcement period in hopes of getting an abnormal return. Negative abnormal returns reflect expected returns are greater than actual returns, which implies a negative market reaction. It indicates a decrease in the number of shares outstanding and the stock price of companies fall because existing shareholders do not execute their rights. Abnormal return equals zero means there is no market reaction or any change in stock price which means the rights issue does not affect the prosperity of shareholders (Dananjaya \& Wiagustini, 2015).

Tendelilin (2017), explains there is three forms of the efficient market according to Malkiel \& Fama (1970), classified to Efficient Market Hypothesis/EMH namely: weak form, semi-strong form, and strong form. A capital market can be categorized efficiently if abnormal returns only happen on the day of the rights issue announcement as a form of market reaction to the information published. The stock price in an efficient capital market reflects all information accurately and quickly to the public (Virginia et al., 2012; Dewi \& Dewi, 2017).

Rights issue as one of the corporate actions can cause a market reaction, both positive and negative theoretically and empirically. Investors assume that the company issued a rights issue to strengthen the capital structure and also has provided information that the company has a favorable investment opportunity causing a positive market response (Sartika, 2016). Yakup \& Cahyadi (2016), analyzed 58 companies on the Indonesia Stock Exchange in $2009-2012$ concluded there was a positive impact of the rights issue on stock prices. Other research found the market reacted negatively to the announcement of the rights issue. The stock prices of 12 companies on the Nairobi Stock Exchange experienced a downward trend after the announcement of the rights issue compared to before the announcement was issued (Otieno \& Ochieng, 2015; Pramana et al., 2019). The information asymmetry on the Colombo Stock Exchange has caused a negative market reaction when the announcement of a rights issue was issued which was caused by the investor's assumption that the company issued a rights issue because of overvalued stock prices (Edirisinghe $\&$ Nimal, 2015).

\section{Materials and Methods}

Figure 1 shows the relation between the announcement of the rights issue and the abnormal return to find out the type of reaction and the form of capital market efficiency in Indonesia. Based on the previous findings and analysis, the hypothesis of this study is:

H. There are differences in abnormal returns before and after the announcement of the rights issue.

\begin{tabular}{|c|} 
New Information \\
Announcement of rights issue
\end{tabular}$\longrightarrow \begin{aligned} & \text { Market Reaction } \\
& \text { Abnormal return }\end{aligned}$

Figure 1. Research model

This research is a comparative study of market reactions before and after the announcement of the rights issue on the Indonesia Stock Exchange (IDX) from 2014 to 2018. An event study is used to analyze market reactions caused by rights issue announcements so that the level of Indonesian capital market efficiency will be known. The estimated time of this study is 11 days ( 5 days before and 5 days after the announcement) of the rights issue. The population in this study is all companies listed on the Indonesia Stock Exchange (IDX) and conducted a rights issue from 2014 to 2018 , which was 59 companies. The purposive sampling method is used in determining the sample by considering the following criteria that are shown in Table 1.

Dewi, N. P. L., \& Candraningrat, I. R. (2019). Market reaction to the rights issue announcement on the Indonesia stock exchange. International Research Journal of Management, IT and Social Sciences, 6(6), 264-269. https://doi.org/10.21744/irjmis.v6n6.805 
Table 1

Criteria of sample

\begin{tabular}{ll}
\hline Criterion & Amount \\
\hline Companies that conducted a rights issue from 2014 to 2018 & 59 \\
Companies that have been and/or are incorporated in the LQ45 & -14 \\
Index during the study period & \\
Companies with incomplete data & -9 \\
Amount & 36 \\
Univariate outlier data & -9 \\
Total Sample & 27 \\
\hline
\end{tabular}

The second criterion states that the company is not currently and/or has been incorporated in the LQ45 Index during the study period which is intended to avoid biased results between companies with large and small market capitalization to find out more accurate market reaction due to rights issue announcement.

The calculation of changes in abnormal return will be calculated with Cumulative Abnormal Return (CAR) for 5 days before and 5 days after the announcement of the right issue. CAR will be obtained by calculating the expected return using the Market Adjusted Model which does not use the estimation period, but only the current market index at time $\mathrm{t}$ (IHSGt). The following are steps for calculating the Cumulative Abnormal Return (CAR).

First step: Calculating actual return for each sample (Hartono, 2017).

$\mathrm{R}_{\mathrm{i}, \mathrm{t}}=\frac{P_{t}-P_{t-1}}{P_{t-1}}$

Where :

$\mathrm{R}_{\mathrm{i}, \mathrm{t}} \quad$ : Individual stock return $\mathrm{i}$ at $\mathrm{t}$ period

$\mathrm{P}_{\mathrm{t}} \quad$ : Closing stock price $\mathrm{i}$ at $\mathrm{t}$ period

$\mathrm{P}_{\mathrm{t}-1} \quad$ : Closing stock price $\mathrm{i}$ before $\mathrm{t}$ period

Second step: Calculating market return for each sample (Hartono, 2017).

$\mathrm{R}_{\mathrm{m}, \mathrm{t}}=\frac{I H S G_{t}-I H S G_{t-1}}{I H S G_{t-1}}$

Where :

$\mathrm{R}_{\mathrm{m}, \mathrm{t}} \quad$ : Market return at $\mathrm{t}$ period

$\mathrm{IHSG}_{\mathrm{t}} \quad$ : Indonesia composite index at $\mathrm{t}$ period

$\mathrm{IHSG}_{\mathrm{t}-1}$ : Indonesia composite index before $\mathrm{t}$ period

Third step: Calculating abnormal return for each sample (Tendelilin, 2017).

$\mathrm{AR}_{\mathrm{i}, \mathrm{t}}=R_{i, t}-R_{m, t}$

Where :

ARi,t : Abnormal return of stock $i$ at $t$ period

$\mathrm{R}_{\mathrm{i}, \mathrm{t}} \quad$ : Individual stock return $\mathrm{i}$ at $\mathrm{t}$ period

$\mathrm{R}_{\mathrm{m}, \mathrm{t}} \quad$ : Market return at t period

Last step: Calculating Cumulative Abnormal Return (CAR) for each sample (Tendelilin, 2017).

$\mathrm{CAR}_{\mathrm{i}, \mathrm{t}}=\sum_{a=t 1}^{t=5} A R_{i, t}$

Where :

The company CAR $i$ at $t$ period is accumulated from AR of $i$ securities before the announcement $(t-5)$ to $(t-1)$ and after the announcement of a rights issue $(t+1)$ to $(t+5)$.

Kolmogorov-Smirnov statistic test is used to test the normality of data. The hypothesis analysis technique is the Parametric Statistical Test with a paired sample t-test to test the comparative hypothesis with the condition that the data must be normally distributed. 


\section{Results and Discussions}

Table 2

Descriptive statistic of cumulative abnormal return

\begin{tabular}{lllllll}
\hline & N & Minimum & Maximum & Sum & Mean & Std. Deviation \\
\hline CAR before & 27 & -0.1518 & 0.0892 & -0.6918 & -0.0256 & 0.0522 \\
CAR after & 27 & -0.2176 & 0.1634 & -0.8114 & -0.0301 & 0.0830 \\
Valid N (listwise) & 27 & & & & & \\
\hline
\end{tabular}

Source: Processed in SPSS, 2019

Tendelilin (2017), states that Cumulative Abnormal Return (CAR) should be equal to zero if the market is efficient. A positive or negative CAR implies an inefficient market because the information is not fully contained in the stock price at the announcement date. Based on Table 2 shows negative Cumulative Abnormal Return both before and after the announcement of the rights issue. The discovery of a total Cumulative Abnormal Return (CAR) before the announcement date of -0.6918 and after the announcement date of -0.8114 indicates that the Indonesian capital market is classified as less efficient because the stock price does not reflect all information provided in the market.

Table 3

One-Sample Kolmogorov-Smirnov normality test

\begin{tabular}{llll}
\hline & & CAR before & CAR after \\
\hline $\mathrm{N}$ & & 27 & 27 \\
Normal Parameters & & -0.0256 & -0.0301 \\
& Mean & 0.0522 & 0.0830 \\
Most Extreme & Std. Deviation & 0.162 & 0.154 \\
Differences & Absolute & 0.162 & 0.154 \\
Test Statistic & Positive & -0.103 & -0.115 \\
Asymp. Sig. (2-tailed) & Negative & 0.162 & 0.154 \\
\hline
\end{tabular}

Source: Processed in SPSS, 2019

Based on Table 3, the Asymp. Sig. (2-tailed) Cumulative Abnormal Return (CAR) before the announcement date of the right issue is $0.068^{\mathrm{c}}$ and after the announcement date is $0.101^{\mathrm{c}}$ which is greater than the significance level of $5 \%$ $(0.068 c>0.05$ and $0.101 c>0.05)$, then both data are normally distributed.

Table 4

Paired sample t-test of the hypothesis test

\begin{tabular}{|c|c|c|c|c|c|c|c|c|}
\hline & \multirow[b]{2}{*}{ Mean } & \multirow{2}{*}{$\begin{array}{l}\text { Std. } \\
\text { Deviation }\end{array}$} & \multirow{2}{*}{$\begin{array}{l}\text { Std. Error } \\
\text { Mean }\end{array}$} & \multicolumn{2}{|c|}{$\begin{array}{l}\text { 95\% Confidence } \\
\text { Interval of the } \\
\text { Difference }\end{array}$} & \multirow[b]{2}{*}{$\mathrm{t}$} & \multirow[b]{2}{*}{$\mathrm{df}$} & \multirow[b]{2}{*}{ Sig. (2-tailed) } \\
\hline & & & & Lower & Upper & & & \\
\hline $\begin{array}{l}\text { CAR before } \\
\text { CAR after }\end{array}$ & 0.0044 & 0.0929 & 0.0179 & -0.0323 & 0.0412 & 0.248 & 26 & 0.806 \\
\hline
\end{tabular}

Source: Processed in SPSS, 2019

Based on Table 4, the data were calculated with SPSS through the Paired Sample t-test method is shown in the Sig. (2-tailed) of 0.806 is greater than the $5 \%$ significance level $(0.806 \geq 0.05)$ means there is no difference in abnormal returns before and after the announcement of the rights issue, which implies that there is no market reaction from the information on the announcement of the rights issue on the Indonesia Stock Exchange.

The descriptive statistical shown in Table 2 states that there are negative abnormal returns both before and after the announcement date, but the hypothesis test of the Paired Sample t-test on Table 3 concludes that there is no change in

Dewi, N. P. L., \& Candraningrat, I. R. (2019). Market reaction to the rights issue announcement on the Indonesia stock exchange. International Research Journal of Management, IT and Social Sciences, 6(6), 264-269. https://doi.org/10.21744/irjmis.v6n6.805 
abnormal means there is no market reaction due to this corporate action. The absence of market reaction to the rights issue can be caused by several factors, including (1) The lack of accurate information in the market, so that investors cannot make certain decisions to execute or not to their rights; (2) The lack of sophisticated investors in analyzing and interpreting available information, resulting in shareholders failure to obtain abnormal returns; (3) There is a dominance number of traders compared to investors who focus on short-term profits or return, so they do not conduct right issue transactions that are considered unable to give return at that time. Supporting the statement in Suresha \& Chandrashekara (2016), that no difference in abnormal returns indicating low market enthusiasm due to low investor awareness on rights issue information.

The results of this study support research conducted by Ogada \& Kalunda (2017), which states that the right issue information does not affect market returns in Kenya. Kendirli \& Elmali (2016), and Mariko (2016), who stated that the announcement of rights issue had no effect on stock prices as indicated by no change in the average abnormal return. Rohit et al., (2016), explains that there is no impact from the announcement of the rights issue in India which indicates the Indian capital market is half-strong (semi-strong form). Wiagustini et al., (2017), concluded that there was no difference in abnormal return both before and after the announcement of the rights issue so that the Indonesian capital market was classified as semi-strong.

The results of this study can also reflect that the Indonesian capital market as a semi-strong form based on the Efficient Market Hypothesis/EMH by Malkiel \& Fama (1970). The Indonesian capital market is classified as semistrong because market prices are formed from past and present information that has been published. Abnormal returns also only occur at the time of the announcement and around the date of the announcement as a market response to the new information. Newmarket prices are formed when new information is published by the company. The market will speculate that causes overadjusted or under adjusted before the new equilibrium price is formed. Investor speculation is reflected in the negative Cumulative Abnormal Returns (CARs) both before and after the announcement of the rights issue, implies that there is a negative market reaction which reflects the decline in shareholder prosperity caused by the fall in stock prices, due to negative investor perceptions of the rights issue issued by the company.

\section{Conclusion}

Following the study findings, it was possible to conclude that the announcement of the right issue does not influence the market reaction as indicated by the absence of changes in abnormal returns both before and after the announcement. There is a downward trend of abnormal return which is proxied in the Cumulative Abnormal Return (CAR) implies a negative market reaction means there is a decline in the prosperity of existing shareholders as reflected by the fall in the company's stock price. Finally, results led to the conclusion that the Indonesian Stock Exchange is classified as a semi-strong form due to the discovery of abnormal returns as a form of market response to the rights issue around the announcement date.

\section{Conflict of interest statement}

The authors declared that they have no competing interests.

Statement of authorship

The authors have a responsibility for the conception and design of the study. The authors have approved the final article.

\section{Acknowledgments}

The authors would like to thank family and friends who have supported them to finish this research study. 


\section{References}

Balachandran, B., Kanapathippillai, S., Krishnamurti, C., Theobald, M., \& Velayutham, E. (2017). The issuance of warrants in rights offerings: Agency costs and signaling effects. Australian Journal of Management, 42(4), 608636. https://doi.org/10.1177\%2F0312896216682062

Dananjaya, I. B., \& Wiagustini, N. L. P. (2015). Studi komparatif abnormal return sebelum dan sesudah merger pada perusahaan di BEI. E-Jurnal Manajemen, 4(4).

Dewi, I. G. A. A. O., \& Dewi, I. G. A. A. P. (2017). Corporate social responsibility, green banking, and going concern on banking company in Indonesia stock exchange. International Journal of Social Sciences and Humanities, 1(3), 118-134. https://doi.org/10.29332/ijssh.v1n3.65

Di Martino, G., \& Busatto, F. (2018). Equity Rights Issue and Dilutive Effect: Evidence from Italian Listed Companies. International Business Research, 11(10), 94-110. https://doi.org/10.5539/ibr.v11n10p94

Edirisinghe, U. C., \& Nimal, P. D. (2015). Stock Price Reaction to Announcements of Right Issues and Debenture Issues: Evidence from Colombo Stock Exchange. International Journal of Business and Social Research, 5(2), 6776.

Hartono, J. (2017). Teori portofolio dan analisis investasi edisi kesebelas. Yogyakarta, Id: BPFE-Yogyakarta.

Kendirli, S., \& Elmali, M. E. (2016). The effects of right offering announcements on returns of shares of deposit banks traded in istanbul stock-exchange. Journal of Economic Development, Environment and People, 5(1), 74-82.

Malkiel, B. G., \& Fama, E. F. (1970). Efficient capital markets: A review of theory and empirical work. The journal of Finance, 25(2), 383-417. https://doi.org/10.1111/j.1540-6261.1970.tb00518.x

Mariko, B. J. (2017). Effect of new information from rights issue announcement on share prices of firm's listed on the nairobi security exchange. American Journal of Finance, 1(3), 54-70.

Ogada, A., \& Kalunda, E. (2017). Impact of Rights Issue on Share Returns of Firms Listed on The Nairobi Securities Exchange, Kenya.

Otieno, O. D., \& Ochieng, D. E. (2015). The effects of Rights Issue Announcements on Stock Returns for Firms Listed at the Nairobi Securities Exchange. International Journal of Education and Research, 1(9), 411-426.

Pramana, Y., Suprasto, H. B., Putri, I. G. A. M. D., \& Budiasih, I. G. A. N. (2019). Fraud factors of financial statements on construction industry in Indonesia stock exchange. International Journal of Social Sciences and Humanities, 3(2), 187-196. https://doi.org/10.29332/ijssh.v3n2.313

Pratama, I. G. W., \& Rahyuda, H. (2019). Performance of stock portfolio based on contrarian strategy in indonesia stock exchange. International Research Journal of Management, IT and Social Sciences, 6(6), 220-228. https://doi.org/10.21744/irjmis.v6n6.797

Putra, I. G. W. R., \& Sedana, I. B. P. (2019). Capital structure as a mediation variable: Profitability and liquidity on company value in real estate companies in Indonesia stock exchange. International Research Journal of Management, IT and Social Sciences, 6(4), 62-72. https://doi.org/10.21744/irjmis.v6n4.640

Rohit, B., Pinto, P., \& Shakila, B. (2016). Impact of Stock Splits and Rights Issue Announcements on Market Price: Evidence From India. Drishtikon: A Management Journal, 7(2), 1.

Sartika, F. (2016). The Effect of Growth Opportunities, Issue Size, Leverage, Ownership Concentration, and Subscription Price Discount Toward Cumulative Abnormal Return: Study on Right Issue Event. Global Journal of Business and Social Science Review, 4(3), 98-107.

Sihaloho, L. E., \& Handayani, S. R. (2018). Perbedaan kinerja keuangan perusahaan sebelum dan sesudah right issue (Studi Pada Perusahaan yang Terdaftar di Bursa Efek Indonesia (BEI) Non Perbankan dan Lembaga Keuangan Periode Tahun 2014 dan 2015). Jurnal Administrasi Bisnis, 61(3), 134-143.

Suresha, B., \& Chandrashekara, B. (2016). Market Efficiency Around Bonus, Stock Split and Rights Issue Announcement-Evidence from India. Journal of Economics and Sustainable Development, 7(11), 71-79.

Tandelilin, E. (2017). PasarModal: Manajemen Portofolio dan Investasi. PT Kanisius, Yogyakarta.

Virginia, S., \& Manurung, E. T. (2012). Pengaruh Pengumuman Earnings Terhadap Abnormal Return Saham. Jurnal Administrasi Bisnis, 8(1).

Wiagustini, N. L. P., Sedana, I. B. P., \& Badjra, I. B. (2017). Market reaction and semi strong efficiency test. International Journal of Research in Commerce, Economic, and Management, 7(4), 1-7. http://ijrcm.org.in/

Yakup, W. Y., \& Cahyadi, Y. (2016). Analysis of Right Issue Announcement Effect toward Stock Price Movement and Stock Trading Volume within Issuer in Indonesia Stock Exchange. Binus Business Review, 7(1), 33-38.

Dewi, N. P. L., \& Candraningrat, I. R. (2019). Market reaction to the rights issue announcement on the Indonesia stock exchange. International Research Journal of Management, IT and Social Sciences, 6(6), 264-269. https://doi.org/10.21744/irjmis.v6n6.805 